\title{
Legitimate Expectations in Canada: Soft Law and Tax Administration
}

Sas Ansari

Lorne Sossin

Osgoode Hall Law School of York University, Isossin@osgoode.yorku.ca

Source Publication:

Legitimate Expectations in the Common Law World, eds. Matthew Groves and Greg Weeks, (London: Hart, 2016)

Follow this and additional works at: https://digitalcommons.osgoode.yorku.ca/scholarly_works

Part of the Administrative Law Commons, and the Tax Law Commons

\section{Recommended Citation}

Ansari, Sas and Lorne Sossin. "Legitimate Expectations in Canada: Soft Law and Tax Administration" In Legitimate Expectations in the Common Law World, eds. Matthew Groves and Greg Weeks, (London: Hart, 2017): 293-317.

This Book Chapter is brought to you for free and open access by the Faculty Scholarship at Osgoode Digital Commons. It has been accepted for inclusion in Articles \& Book Chapters by an authorized administrator of Osgoode Digital Commons. 
Osgoode Legal Studies Research Paper No. 30

Vol. 13/ Issue. 6/ (2017)

\title{
Legitimate Expectations in Canada: Soft Law and Tax Administration
} Legitimate Expectations in the Common Law World, Hart Publishing, 2016, Forthcoming.

\author{
Sas Ansari \\ Lorne Sossin
}

\begin{abstract}
:
This chapter examines the relationship between legitimate expectations and soft law. In what circumstances can an agency's guidelines create law - or at least legally enforceable expectations? At first glance, the answer would appear obvious. The key reason for developing soft law is to provide guidance and transparency as to the process (and sometimes the substance) of administrative action. Soft law by its nature gives rise to expectations. Whether those expectations, in turn, give rise to legal effects is decidedly less clear. In fact, this question has vexed Canadian administrative law. Nowhere are questions of soft law 1 and legitimate expectations more salient than in the context of tax administration.

\section{Author(s):}

Sas Ansari

Osgoode Hall Law School, York University

E: sasanansari@osgoode.yorku.ca

Lorne Sossin

Osgoode Hall Law School, York University

E: lsossin@osgoode.yorku.ca
\end{abstract}




\title{
Legitimate Expectations in Canada: Soft Law and Tax Administration
}

\author{
SAS ANSARI AND LORNE SOSSIN
}

$\mathrm{T}$

HIS CHAPTER EXAMINES the relationship between legitimate expectations and soft law. In what circumstances can an agency's guidelines create law—or at least legally enforceable expectations? At first glance, the answer would appear obvious. The key reason for developing soft law is to provide guidance and transparency as to the process (and sometimes the substance) of administrative action. Soft law by its nature gives rise to expectations. Whether those expectations, in turn, give rise to legal effects is decidedly less clear. In fact, this question has vexed Canadian administrative law. Nowhere are questions of soft law ${ }^{1}$ and legitimate expectations more salient than in the context of tax administration.

We canvass the relationship between legitimate expectations and soft law in the context of Canadian tax administration. The analysis proceeds in three parts. In the first part, we consider the important roles of soft law in a tax administration system premised on self-assessment. Within this analysis, we list and describe six sources of soft law in the tax administration context. In the second part, we explore the development of the doctrine of legitimate expectations in Canada, and the implications of the Supreme Court of Canada's (SCC) most considered treatment of soft law and legitimate expectations in Agraira $v$ Canada. ${ }^{2}$ The third part of the chapter analyses

\footnotetext{
1 Soft law is the generally recognised term for official instruments of various forms which are non-binding and seek to guide, clarify or affect administrative action. Soft law is most often distinguished from 'hard law' such as statutes and regulations which are binding and set out legally enforceable standards, duties and powers. Another term for guidelines is 'interposed law', which Professor William Twining differentiated from 'soft law' in his keynote lecture at the 2014 Osgoode Forum, 10 May 2014, in Toronto, Ontario. He defined interposed law as including the 'descriptions of law that tax administrators develop and that come between the tax code and the practice of tax administration by administrators'. The importance of this 'interposed law' was highlighted by reference to a hypothetical investor who, in making investment decisions, would analyse the risks/benefits of the investment not only on the 'state law' but also the very important 'interposed laws' that are of practical importance.

2 Agrairav Canada [2013] 2 SCR 559 ('Agraira').
} 
when (and pursuant to which principles) soft law in the tax administration context (eg information circular, interpretation bulletin, or advance judgment) may give rise to a legitimate expectation.

We conclude that Canadian administrative law has only begun to grapple with legitimate expectations, and that its development in the context of soft law represents an important catalyst for sorting out a more coherent and transparent framework for the review of administrative action.

\section{SOFT LAW AND TAX ADMINISTRATION}

The Canada Revenue Agency (CRA) is a large administrative agency ${ }^{3}$ that performs various functions, including both 'judicial rights-determining functions' and 'administrative rights determining functions', ${ }^{4}$ in pursuit of the administration and enforcement of the Income Tax Act (ITA). ${ }^{5}$ The ITA is 'complex' 6 and 'convoluted', and is filled with provisions that are ambiguous and unclear. ${ }^{8}$ The CRA recognises the lack of clarity in the ITA. ${ }^{9}$ The words of Justice Learned Hand are quite appropriate in describing the complexity of tax law: ${ }^{10}$

The words of such an act as the Income Tax, for example, merely dance before my eyes in a meaningless procession: cross-reference to cross-reference, exception

3 The CRA is properly considered an administrative agency, separate from the Minister of Revenue. From its start in 1867 as the Department of Customs and the Department of Inland Revenue (The Customs Act 30-31 Vict c 6 and The Inland Revenue Act, 30-31 Vict c 8), the tax administration agency was renamed and reformed a number of times. In response to increased criticism of the potential political nature of having taxes administered by an elected official, the Government of Canada created a federal agency that, since 2005, has been called the Canada Revenue Agency. The CRA is headed by a Commissioner of Revenue who is authorised by the Minister of Revenue to exercise the Minister's powers. However, the Minister continues to play a role and has (in law) the power to direct the Commissioner to exercise any powers, duties, or functions.

4 These phrases, referring to the various functions that administrative bodies can perform, are taken from the four-part classification in Ron Ellis, Unjust by Design: Canada' Administrative Justice System (University of British Colombia Press, 2013).

5 Income Tax Act, RSC 1985 c 1 (5th Supp) at subsection 220(1).

6 See eg, Weaver $v$ The Queen 2008 FCA 238 [11], [18].

7 See eg, Boulay $v$ The Queen 2003 TCC 96 [7].

8 Canadian courts have repeatedly referred to the ITA in these terms and have noted that many of the ITA's provisions are 'ambiguous or unclear' (see eg, Canada v Brelco Drilling Ltd, [1999] 4 FC 35). The Supreme Court of Canada, in 65302 British Colombia Ltd v Canada [1999] 2 SEC 804 [51], described the ITA as 'the most detailed, complex, and comprehensive statutes in [Canada's] legislative inventory'.

9 See eg the statements of CRA officials in a meeting of tax officials outlying the customer service approach to tax administration (quoted in Lorne Sossin, 'The Politics of Discretion: Toward a Critical Theory of Public Administration' (1993) 36 Canadian Public Administration 364, 387-88).

10 Learned Hand, 'Eulogy of Thomas Walter Swan' (1947) 57 Yale Law Journal 167, 169. Although referring to the US income tax law, the comments are apt when describing most tax statutes. 
upon exception-couched in abstract terms that offer no handle to seize hold ofleave in my mind only a confused sense of some vitally important, but successfully concealed, purport, which it is my duty to extract, but which is within my power, if at all, only after the most inordinate expenditure of time.

Complexity is increased by tax law's secondary-law nature. ${ }^{11}$ Tax law must take the legal world (which gives legal significance to real-world events and actions, on which tax law then operates) as it finds it. Unless the ITA expressly or by necessary implication modifies the legal terrain, tax law only applies after the other laws have exerted their effects. This is a daunting task even for seasoned tax lawyers. Not surprisingly, taxpayers often do not understand the tax consequences of their choices and life-events. In recognition of this complexity and the reality of inherent uncertainties in statutory interpretation, the Mintz Committee recommended that taxpayers and the Minister be allowed to enter into compromise settlements on the basis of litigation risk. ${ }^{12}$

This complexity could be significantly reduced, if not resolved, by applying professional expertise (lawyers, accountants, etc) ${ }^{13}$ but for the fact that, in order to function as designed, Canada's income tax system must (at least passively) engage with over 26 million individual taxpayers annually. ${ }^{14}$ The majority of taxpayers have no legal or tax experience or training and cannot afford to retain tax experts (nor should they be required to within the context of a self-assessing system). The onus of correctly interpreting the law, identifying legally significant facts, and applying the law to these factscoming up with the correct amount of tax owing-is on the taxpayer. ${ }^{15}$ Where the taxpayer fails at this, s/he may face interest charges ${ }^{16}$ and (both criminal and non-criminal) penalties, ${ }^{17}$ possibly exceeding the taxpayer's

11 See eg the SCC decision in Will-Kare Paving \& Contracting Ltd $v$ Canada [2000] 1 SCR 915, where the Court stated that the ITA does not operate in a vacuum, and that legal characterisation of the broader commercial relationships and law affect the operation and effect of the ITA.

12 Canada, Report of the Technical Committee on Business Taxation (Department of Finance, 1998).

13 Of course, these professionals do not always agree, inter- and intra-professions, as to the meaning and effect of all of the provisions of the ITA (and other areas of law).

14 CRA statistics for the 2013 tax year, available online at www.cra-arc.gc.ca/gncy/stts/ itsa-sipr/2013/menu-eng.html accessed on 1 March 2016.

15 Tax administration using a self-assessment process has been described as 'the ultimate delegation of decision making in an income tax system, because it allows the taxpayer to control to the greatest degree possible the process of determining their tax liability'. See Michael Walpole, 'Ethics and Integrity in Tax Administration' (12 September 2009) UNSW Law Research Paper No 2009-33, 1, available online at http://ssrn.com/abstract=1474100.

16 ITA s 161.

17 The penalty provisions in the ITA include: s 162-failure to file annual returns; s 163 false statements and omissions; s 188.1—penalties for charities; and s 227-failure to deduct and withhold as required. 
tax liability. ${ }^{18}$ CRA employees who judge and analyse taxpayers' tax returns are faced with the same lack of certainty and clarity in interpreting and applying the complex and convoluted provisions of the ITA, often with little more expertise and education than most taxpayers. ${ }^{19}$

One policy of tax legislation is the creation of tax law that is 'certain, predictable and fair, so that taxpayers can intelligently order their affairs' ${ }^{20}$ Meeting this policy goal in a 'self-assessment system, which requires individuals without legal training to work through a complex series of provisions [...] for which maximum guidance is necessary' ${ }^{21}$ is in part achieved through the creation and distribution of detailed guidelines. ${ }^{22}$ The CRA, in order to serve its various functions, 'distills from the statutory text the particulars of the legislator's policy intentions, and drafts and "enacts" the directive and the rules and regulations necessary to give effect to those particulars'. ${ }^{23}$ These agency-created documents, referred herein collectively as 'guidelines', are the focus of this chapter. ${ }^{24}$

This soft law is used in the course of giving effect to the statutory rights granted and obligations imposed by the ITA. ${ }^{25}$ They guide the decisions of various CRA employees involved in determining the existence of and the outcome of disputes between taxpayers and the state that arise in the ordinary course of administrating the ITA. They are also heavily employed by lawyers and tax professionals in providing services to taxpayers, and are used by taxpayers themselves to make sense of the Canadian income tax

18 The ITA contains complex provisions for penalties that apply in a variety of circumstances. For example see John Sorensen, Michael Belz and Shiri Trop, 'Non-Criminal Penalties under the Income Tax Act' in 2013 Ontario Tax Conference (Canadian Tax Foundation, 2013) 12:1.

19 Many positions within the CRA require no legal or tax education, eg the CRA's advertisement for a 'Tax Services Agent', whose duties include responding 'to business enquiries related to registrations, payroll deductions, GST/HST, self-employment, and corporate income tax', are only required to have education that is a 'secondary school diploma' or equivalent: www. cra-arc.gc.ca careers section, notice accessed 30 July 2014. A copy of the job notice is on file with the authors.

20 Canada Trustco Mortgage Co v Canada 2005 SCC 54 [42].

21 British Colombia Ltd v Canada (n 8) [57].

22 The ITA in PDF form is 3,236 pages long and the Regulations take up another 1,645 pages. The text of the four sections dealing with 'Income and Loss from an Office or Employment', the simplest of the provisions in the ITA, covers 50 of those pages. The CRA has issued a number of guidelines to deal with these four sections, totaling another 50 pages of explanations covering only small portions of those four sections. These four sections do not cover other sources of income, investment income, excluded amounts, deductions, credits, or other matters commonly encountered by most taxpayers.

23 See Ellis (n 4) 135 where such functions are said to be performed by the 'policy and legislative department' of the 'portfolio ministry' of the executive branch of government.

24 The first such publication by Canada Revenue (as it then was) was in 1970, and consisted of two series of publications: 'Information Circulars' and 'Interpretation Bulletins'.

25 The TCC in Dunlap $v$ The Queen 52 DTC 2053, held that the 'principal purpose of the bulletins is to inform the public of policies which the [Minister] has adopted for the administration of legislation as broad and complex as the Income Tax Act'. 
system. This is why soft law plays as crucial a role in the smooth functioning of a self-assessment system, the exercise of discretion by CRA officials, and the compliance efforts of taxpayers.

\section{Guidelines and the Integrity of the Tax System}

Canada's self-assessment system relieves the tax authority of the duties normally imposed on assessors freeing up resources for administration and enforcement. ${ }^{26}$ This is not without cost. A self-assessment system provides greater opportunities for tax avoidance and evasion, undermining the tax base and reducing government revenues. ${ }^{27}$ Tax avoidance and evasion increase where, inter alia, ${ }^{28,29}$ the tax system is perceived as being unfair. ${ }^{30}$ In a self-assessment system, 'fairness and even handedness by the tax authority are required to encourage integrity among taxpayers', and perceptions of unfair treatment by the tax authority have an 'important influence on future levels of tax evasion'. 31

The importance of taxpayer trust within a self-assessment system, and the effects of perceptions of fairness, is well recognised by the Canadian Government and courts. ${ }^{32}$ In an increasingly complex and changing legal landscape, actors ought to be able to rely on law with some certainty. ${ }^{33}$ Where the law involves administrative discretion, ${ }^{34}$ is complex, or is otherwise uncertain, the public will have difficulty in predicting how discretion will

26 Michael Walpole, 'Ethics and Integrity in Tax Administration' in Surviving Challenges, Seizing Opportunities, Inland Revenue Board Malaysia, Malaysia, presented at National Tax Conference, Kuala Lumpur, 4-5 August 2009 at p 10, available online at http://ssrn.com/ abstract $=1474100$.

27 Vito Tanzi and Parthasarathi Shome, 'A Primer on Tax Evasion' (Dec, 1993) 40:4 Staff Papers-International Monetary Fund 807, 810.

28 Ibid, 819. See also James Alm, Isabel Sanchez, and Ana de Juan, Economic and Noneconomic Factors in Tax Compliance (Blackwell Publishing, 1995) Vol 48(1), 3-18.

29 Robert Halperin and Joseph Tzur, 'Tax Evasion and the Low Penalty, Low Audit Rate Phenomenon' (1990) 9 Journal of Accounting and Public Policy 179, 179.

30 Michael Walpole, 'Ethics and Integrity in Tax Administration' (12 September 2009) UNSW Law Research Paper No 2009-33 at pp 12-13, available online at http://ssrn.com/ abstract $=1474100$. See also Soren Schønberg, Legitimate Expectations in Administrative Law (Oxford University Press, 2000).

31 Walpole (n 30) 13.

32 For example, in the Federal Court of Appeal in Hawkes $v$ The Queen [1997] 2 CTC 133 (FCA) [7], Strayer JA observed that tax administrators must avoid conduct that damages the perception of the 'system as fair, equitable, and reasonable in application'.

33 See Schønberg (n 30) 9.

34 In the income tax context, discretion may be discretion expressly granted by the ITA, may be implied in the implementation of public polices, may materialise in the interpretation given to unclear or ambiguous provisions, or may be implicit in the everyday interactions of tax administrators with taxpayers. See Lorne Sossin, 'The Politics of Discretion' (1993) Canadian Public Administration 36:3, 364, 384. 
be exercised or the law will be interpreted and applied. ${ }^{35}$ Clearly worded and easy to understand representations by public authorities will, in cases of ambiguity, serve to guide an individual's actions and decisions. ${ }^{36}$ Therefore, how the law treats soft law may undermine taxpayers' perceptions of fairness. ${ }^{37}$ For example, the failure of courts to allow into evidence such things as government policy concerning the application of certain rules of evidence of the treatment of similar taxpayers is seen as having a negative effect. ${ }^{38}$

\section{Soft Law and Tax}

There are a large number of tax guidelines that could be considered for the purposes of this analysis. The authority for developing soft law is not expressly found in the ITA, but is implied by provisions empowering the Minister to administer the ITA. A small subset of these sources of soft law includes:

(i) Income Tax Folios ('ITF');

(ii) Income Tax Information Circulars ('IC');

(iii) Income Tax Interpretation Bulletins ('IT');

(iv) Income Tax Technical News ('ITTN');

(v) Tax Guides and Pamphlets; and

(vi) Advanced Income Tax Rulings ('ATR'). ${ }^{39}$

There are other publications that are publicly available even if designed for use by expert specialists rather than members of the public. This category includes the CRA Appeals Manual, and other statements and communications by the CRA (both written and oral, and formal and informal). ${ }^{40}$ Relevant statements and publications could also include those made by the Department of Finance (for example comfort letters, news releases, tax bulletins, technical papers).

35 See Schønberg (n 30) 14.

36 Schønberg (n 30) 29. Schønberg saw this as fundamental to the Rule of Law (at 13).

37 See Revenue Canada, Ensuring Fair Customs and Revenue Administration in Canada: A Discussion Paper on Progress and Innovation to Comment (Revenue Canada, 1998) at foreword.

38 A Meghji and S Sieker, 'A Contest of Unequals: Recent Developments in Tax Litigation' in Report of the Proceedings of the Forty-Ninth Tax Conference, 1997 Tax Conference (Canadian Tax Foundation, 1998) 11:1, 11:22.

39 See Benjamin Alarie, Kalmen Datt, Adrian Sawyer and Greg Weeks, 'Advance Tax Rulings in Perspective: A Theoretical and Comparative Analysis' (2014) 21 New Zealand Journal of Taxation Law and Policy 362; Woon v MNR [1950] CTC 263 (Ex Ct).

40 These documents are obtained and made publicly available by private entities though freedom of information requests. 
Of the above, ITFs and ICs are intended for use by both taxpayers and tax professionals, ITTNs and ITs are intended for tax professionals, Tax Guides and Pamphlets are intended for taxpayers and the general public, ${ }^{41}$ and ATRs are applicable to specific transactions. Despite the distinction in use, all of them are written in clear language and appear easy to understand/ apply by taxpayers without recourse to tax professionals. ITFs, ${ }^{42}$ ITTNs, and ITs are subject to general notices that appear to be aimed at limiting the reasonableness of replying on the information they contain, often referring the reader back to the ITA, Regulations, and relevant cases. ICs are not subject to a general notice, though specific ICs contain statements as to when they do and do not apply, including that they are not meant to replace the spirit or intent of legislation. ${ }^{43}$ Tax Guides and Pamphlets and ATRs do not contain any notices, but ATRs are issued to taxpayers and are considered by the CRA to be binding only for that one taxpayer and only within the facts detailed. Despite the various notices, the wording of which is different in the various soft-law instruments, given the complexity of income tax law and the vast volume of 'incomprehensible' text in the statute and regulations, we would suggest that reliance may be necessarily invited by the simple act of making available more accessible and understandable descriptions of the law.

In light of the range of sources of soft law in the context of tax administration, discussed above, how should the legal effects of these instruments be understood? Are instruments intended for use by tax professionals to be considered as giving rise to greater/lesser expectation than those intended for taxpayers? Are instruments which are not publicly circulated (but which are not secret either) be considered to create greater/lesser expectation than those posted on the CRA website? Given the disclaimers that routinely accompany all these instruments, to the effect that none of them 'replace the law', should they give rise to legal consequences? Is a taxpayer who relies on the content of these instruments to his/her detriment within his/her rights to seek a remedy on the basis an expectation has been frustrated?

In order to answer these fundamental questions, it is necessary review the treatment of legitimate expectation in Canadian administrative law.

\footnotetext{
41 Guides are often accompanied with forms and directions on how to fill out and file those forms.

42 ITFs state that they are updated when interpretations change or major developments occur, leading a reader to trust that the information is current. ITFs also expressly state that the folio chapters can be relied upon as an accurate summary of the CRA's interpretation of the law-see for example the first paragraph in the Medical Expense Tax Credit Folio-S1-F1-C1, available online at www.cra-arc.gc.ca/tx/tchncl/ncmtx/fls/s1/f1/s1-f1-c1-eng.html.

43 See for example paragraphs 3 to 5 in IC12-1, 'GST/HST Compliance Refund Holds', available online at www.cra-arc.gc.ca/E/pub/tp/ic12-1/ic12-1-12e.pdf; IC00-1R4 [7].
} 


\section{LEGITIMATE EXPECTATIONS AND SOFT LAW}

Soft law can be described both by what it is and what it is not. ${ }^{44}$ In the first (descriptive) sense, soft law includes a wide range of instruments, from guidelines to circulars, policy statements to protocols, which influence a decision-making process. All of the CRA guidelines outlined above qualify as soft law (at least on this standard). In the second (legal) sense, soft law refers to any rules which affect decision-making but are by design or definition non-binding, and so not 'law'. In the Canadian context, 'hard law' would represent all statutory provisions and rules emanating from instruments delegated by statutes to be binding (eg regulations, by-laws, etc). Hard law, in other words, is what authorises CRA officials, on behalf of the Minister, to make decisions. Soft law represents everything else that shapes the resulting exercise of the discretion created by hard law.

Because the CRA itself promulgates the guidelines discussed above, is it reasonable for taxpayers and tax preparers to expect the CRA to rely and make decisions based on their contents? This question is not as straightforward as it sounds. The guidelines themselves make apparent that they are not intended to replace the law. How can officials be held accountable for applying or not applying non-binding instruments? However, it appears to be unfair for those interacting with CRA officials to be given information about how the CRA will interpret and apply the ITA if those officials can disregard the information at any time for any reason. Further, the CRA does not treat these different instruments alike. While ITTNs are simply informational, the ITs are clearly intended to disclose how certain matters are likely to be approached by the CRA. ITFs appear to be hybrid instruments which inform and advise. Tax administration needs a spectrum of legal relevance rather than an on/off switch that would simply create or not create legally relevant expectations.

\section{Legitimate Expectations and the Supreme Court of Canada}

Canada lacks a detailed conceptual framework for the application of legitimate expectations. ${ }^{45}$ The very first detailed discussion of legitimate

44 See F Houle and L Sossin, 'Tribunals and Guidelines: Exploring the Relationships between Fairness and Legitimacy in Administrative Decision-Making' (2006) 46 Canadian Public Administration 283.

45 For a notable exception, see David Wright, 'Rethinking the Doctrine of Legitimate Expectations in Canadian Administrative Law' (1997) 35 Osgoode Hall Law Journal 139. For an example of a more systematic approach in the UK setting, see Adam Perry and Farrah Ahmed, 'The Coherence of the Doctrine of Legitimate Expectations' (2014) 73 Cambridge Law Journal 61. 
expectations by the SCC took place in Martineau in the context of soft law. ${ }^{46}$ In that decision, the majority of the Court provided a closer analysis of the duty to act fairly based on the English fairness doctrine. An inmate in a federal penitentiary challenged a conviction for a disciplinary offence relying in part on departures from a Commissioner's Directive providing procedural safeguards/rights. The majority referred to Lord Denning's decision in Schmidt, ${ }^{47}$ where the doctrine of legitimate expectations was first introduced in English law.

In discussing the role and effect of 'fairness', the majority stated that 'natural justice and fairness are principles of judicial process deemed by the common law to be annexed to legislation, with a view to bringing statutory provisions in conformity with the common law requirements of justice'. ${ }^{48}$ The majority held that, between the poles of 'purely ministerial decisions' on board policy grounds that attract no procedural protection and judiciallike functions that attract substantial procedural safeguards, ${ }^{49}$ there exists 'a myriad decision-making processes with a flexible gradation of procedural fairness through the administrative spectrum' ${ }^{50}$ Dealing specifically with the application of the Commissioner's Directives, the majority stated that the courts are not concerned with:

breaches of the prison rules, but whether there has been a breach of the duty to act fairly in all circumstances, ... the rules are of some importance in determining [the question of fairness] as [they are] an indication of the views of the prison authorities as to the degree of procedural protection to be extended to inmates. $^{51}$

The Court attempted to bring together Canadian and English principles in Old St Boniface, ${ }^{52}$ a case arising in the disparate setting of municipal re-zoning. The majority discussed the appellant's argument based on 'a legitimate expectation of consultation' created by the 'conduct of the Committee'. ${ }^{3}$ The majority stated that the English principle merely extends the reach of the rules of natural justice and procedural fairness to give 'a party affected by the decision of a public official an opportunity to make representations in circumstances in which there otherwise would be no such opportunity'. ${ }^{54}$ Legitimate expectation was grounded in the 'conduct of a

46 Martineau v Matsqui Disciplinary Bd [1980] 1 SCR 603 ('Martineau').

47 Schmidt v Secretary of State for Home Affairs [1969] 2 Ch 149 (CA).

48 Martineau (n 46) 627.

49 Martineau (n 46) 628-29.

50 Martineau (n 46) 628.

51 Martineau (n 46) 630.

52 Old St Boniface Residents Assn Inc v Winnipeg (City) [1990] 3 SCR 1170 ('Old St Boniface').

53 Ibid, 1203.

54 Ibid, 1204. 
public official [that lead] a party [...] to believe that his or her rights would not be affected without consultation'. ${ }^{55}$ The majority concluded that, even if there was a legitimate expectation, it would not replace the elaborate statutory scheme with another process of consultation. Some commentators believe that this decision excluded the possibility of substantive legitimate expectations in Canada, ${ }^{56}$ while others believe that it left that possibility open. ${ }^{57}$

The SCC in Reference Re Canada Assistance Plan (BC) (CAP) appeared to resolve the ambiguity regarding legitimate expectations created by Old St Boniface. ${ }^{58}$ This was an appeal from a British Colombia Court of Appeal decision that extended the reach of the legitimate expectations doctrine by restricting the Federal Government Executive's ability to introduce a Bill into Parliament (aimed at reducing a budget deficit) in breach of an agreement between the Federal and Provincial Governments. The Supreme Court found that the Government had abided by the agreement and, since the agreement's funding formula referred to the statute, it could be validly amended by statute. In dealing with the doctrine of legitimate expectations, the Court referred to Old St Boniface, and then drew a distinction between the procedural right to be consulted and the substantive right to give consent. The Court concluded that the creation of substantive rights through the doctrine of legitimate expectations is not supported in Canadian or English cases. The doctrine was said to be part of the rules of procedural fairness, and where it is applicable, it can create additional rights to make representations or to be consulted. The Court concluded that legitimate expectations could not operate to fetter the decision following the representation or consultation. Further, the rules of procedural fairness do not bind a body 'exercising purely legislative functions'. ${ }^{59}$ In other words, one government could not bind future governments by making promises about legislation or policy.

In Baker, ${ }^{60}$ the Court attempted to embed legitimate expectations in the broader duty of fairness and invoked it as one of five non-exhaustive and non-hierarchal 'factors' a court should consider in determining the degree of fairness owed in a particular context. The Court addressed legitimate expectations in the context of soft law in this analysis and held that the

55 Ibid.

56 Geneviève Cartier, “A “Mullanian” Approach to the Doctrine of Legitimate Expectations: Real Questions and Promising Answers' in Grant Huscroft, Michael Taggart, and David J Mullan (eds), Inside and Outside Canadian Administrative Law: Essays in Honour of David Mullan (University of Toronto Press, 2006) 189-90.

57 Wright (n 45) 167.

58 Reference Re Canada Assistance Plan (BC) [1991] 2 SCR 525 ('CAP').

59 Ibid.

60 Baker $v$ Canada (Minister of Citizenship and Immigration) [1999] 2 SCR 817 ('Baker'). 
failure of the decision-maker to follow the applicable guideline or applicable international covenants and agreements did not render the exercise of discretion unfair. ${ }^{61}$

The Court dealt with the legal effect of the publicly available guidelines. Here, the Immigration Manual used by immigration officers provided various criteria and considerations to be assessed in exercising their discretion. In obiter, the Court outlined the doctrine for purposes of determining the content of the duty of fairness. After confirming that a legitimate expectation 'does not create substantive rights', 62 and distinguishing the 'object of the expectation from its legal effects', ${ }^{63}$ the Court stated that:

a legitimate expectation that a certain procedure will be followed [means that] this procedure will be required by the duty of fairness ... [and] a legitimate expectation that a certain result will be reached $[\ldots]$ may require more extensive procedural rights than would otherwise be accorded. ${ }^{64}$

The Court clarified that the doctrine is based on the principle that it will generally be unfair for [administrative decision-makers] to act in contravention of representations as to procedure, or to backtrack on substantive promises without according significant procedural rights'. ${ }^{65}$

For the Court in Baker, the guidelines related more to the substantive review of the reasonableness of the Immigration Officer's exercise of discretion. The Court held that 'the guidelines are a useful indicator of what constitutes a reasonable interpretation of the power conferred by the provision, and the fact that this decision was contrary to the directives is of great help in assessing whether the decision was an unreasonable exercise' of discretion. ${ }^{66}$ Even the discretion to make a decision that is wholly a matter of judgment is granted within certain boundaries. Such a decision must be made 'following an approach that respects [the purpose of the discretion and the values it advances]'. ${ }^{67}$ In this case, the guidelines reflected the proper approach (which also incorporated the approach set out in an international convention to which Canada was a signatory) and the decision's inconsistency with the guideline and the international convention led to the conclusion that the decision was unreasonable.

Subsequently, the Court explored whether a finding of unreasonableness could flow from promissory estoppel if a promise by a decision-maker gives

61 Ibid [29].

62 Ibid [26].

63 Cartier (n 56) 190.

64 Baker (n 60) [26].

65 Baker (n 60) [26].

66 Baker (n 60) [72].

67 Baker (n 60) [74]. 
rise to detrimental reliance. In Mount Sinai, ${ }^{68}$ a government official committed to a process resulting in the relocation of a hospital and then reneged on its approval for the relocation. The majority of the SCC held that it was unnecessary to decide whether a legitimate expectation was created by the Government's representations, and allowed the appeal based upon its interpretation of the applicable statute. Writing for the majority of the Court, Bastarache $\mathrm{J}$ held that the Minister was bound by the prior commitment as the initial exercise of the relevant discretion. ${ }^{69}$ At that point, the Court held the discretion was, in effect, exhausted, and the subsequent attempt to reverse the decision on the relocation was not authorised and not valid. ${ }^{70}$

Binnie $\mathrm{J}$, in a concurring decision with which McLachlin CJ agreed, concluded that the Minister's decision was 'patently unreasonable [... and] reached by a process that was demonstrably unfair' and, therefore, an abuse of discretion. ${ }^{71}$ The respondents were found to have worked closely with the regulators for a long time, developing a 'web of understandings and incremental arrangements with the concurrence indeed the encouragement of successive Ministers' ${ }^{72}$ Binnie J concluded that, where representations are detrimentally relied upon, an estoppel will operate unless a statute or an overriding public interest dictates a contrary result. ${ }^{73}$ Alternatively, an unreasonable ${ }^{74}$ decision may be quashed and, absent an overriding public interest to the contrary, mandamus might then issue to compel the decisionmaker to exercise his or her discretion afresh and according to law. ${ }^{75}$

The minority addressed the respondent's argument that legitimate expectations can give substantive results where the result is not contrary to law and is otherwise within the power of the Minister. While the respondent argued that the doctrine was evolving, ${ }^{76}$ the minority noted that there is a difference between the Canadian and English contexts. In England, it was stated that the doctrine of legitimate expectations 'performs a number of functions that in Canada are kept distinct'. ${ }^{77}$ The doctrine of legitimate expectations in England was seen as having developed into

68 Mount Sinai Hospital Centre $v$ Quebec (Minister of Health and Social Services) 2001

SCC 41 ('Mount Sinai').

69 Ibid, [90].

70 Ibid, [100].

71 Ibid, [66].

72 Ibid, [8].

73 Ibid, [16].

74 The minority referred to a 'patently unreasonable' decision, but this standard was later fused with the 'reasonable' standard in Dunsmuir v New Brunswick 2008 SCC 9 [45].

75 Mount Sinai (n 68) [16].

76 Relying on a number of international and Canadian decisions: Sous-ministre du Revenu du Québec v Transport Lessard (1976) Ltée [1985] RDJ 502; Gingras v Canada [1990] 2 FC 68 (TD), and Bloomfield $v$ Saskatchewan (Minister of Health) [1986] SJ No 675 (QL) (QB).

77 Mount Sinai (n 68) [24]. 
a comprehensive code that embraced the full gamut of administrative relief from procedural fairness at the low end through 'enhanced' procedural fairness based on conduct, thence onwards to estoppel (though it is not to be called that) including substantive relief at the high end. ${ }^{78}$

The high end of relief was seen as an inappropriate intervention in government policy in Canada, absent a challenge under the Canadian Charter of Rights and Freedoms. ${ }^{79}$

The minority stated that the doctrine of legitimate expectations looks to the public authority's clear, unambiguous, and unqualified conduct in exercising power, and requires that the expectation does not conflict with the authority's statutory jurisdiction. ${ }^{80}$ Unlike estoppel, legitimate expectations do not require the person to show awareness of, reliance on, or detriment resulting from the relied on conduct. ${ }^{81}$ This is because the focus of legitimate expectations is the promotion of 'regularity, predictability, and certainty in government's dealing with the public'. ${ }^{82}$ The minority felt that the decision in CAP, referring to Old St Boniface, closed the door on substantive relief, but also stated that if 'the Court is to give substantive relief, more demanding conditions precedent must be fulfilled than are presently required by the doctrine of legitimate expectation'. ${ }^{83}$

One limitation on the legitimate expectations doctrine is that purely ministerial decisions on broad grounds of public policy will not typically afford any procedural protections. ${ }^{84}$ Another limitation is that a public body exercising legislative functions is only liable to judicial supervision as a result of a successful Charter challenge. ${ }^{85}$

78 Mount Sinai (n 68) [26].

79 Canadian Charter of Rights and Freedoms, Part I of the Constitution Act, 1982, being Schedule B to the Canada Act 1982 (UK), 1982, c 11.

80 Mount Sinai (n 68) [29].

81 Mount Sinai (n 68) [30]. Note, however, that in Coughlan, Lord Woolf implied that reliance may be a necessary element; see $R v$ North and East Devon Health Authority: ex parte Coughlan [2001] 1 QB 213. Note also that in Minister for Immigration and Ethnic Affairs $v$ Teoh [1995] HCA 20, the High Court of Australia held that actual reliance was unnecessary.

82 Mount Sinai (n 68) [30], citing with approval SA de Smith, H Woolf and J Jowell, Judicial Review of Administrative Action, 5th edn (Sweet and Maxwell, 1995) 417. The editors state that adding estoppel-type requirements to legitimate expectations would involve unfair discrimination between those who were and were not aware of the representation and would benefit the well-informed or well-advised [and] would also encourage undesirable administrative practice by too readily relieving decision-makers of the normal consequences of their actions' (at 426).

83 Mount Sinai (n 68) [32].

84 An attack on such decisions must be based on abuse of discretion: Mount Sinai (n 68), [33].

${ }^{85}$ Mount Sinai (n 68) [34]. 
Legitimate expectations have also sometimes been labelled to emphasise 'reasonableness' rather than 'legitimacy'. ${ }^{86}$ In Moreau, ${ }^{87}$ for example, it was argued that the applicant had a 'reasonable expectation' that inquiry findings into her conduct as a judge would not result in her dismissal and that she would continue in her role after the impugned action. There is nothing in the facts relied on to locate the basis of these 'reasonable expectations' in 'clear, unambiguous, and unqualified' representations or conduct of the decision-maker. The SCC did not inquire whether there were any legitimate expectations on the basis of which relief was sought, but simply held that 'the doctrine of reasonable expectations does not create substantive rights, and does not fetter the discretion of a statutory decision-maker' ${ }^{88}$ The doctrine was stated only to create and apply to procedural rights, and then only when 'a party affected by an administrative decision can establish a legitimate expectation that a certain procedure would be followed' ${ }^{89}$

A number of SCC decisions refer to the doctrine of legitimate expectations in passing. In Mackin, ${ }^{90}$ dealing with the status of supernumerary judges, the Court did not find that a legitimate expectation had been established, but went on to note that even if one had, the doctrine does not apply to purely legislative functions and does not 'operate to entitle the [person] to a substantive as opposed to procedural remedy'. ${ }^{91}$

In CUPE, ${ }^{92}$ the Court was called upon to determine what factors were relevant and irrelevant to a particular exercise of discretion by the Minister of Labour to appoint interest arbitrators, and looked to the history of the legislation to identify its purpose. ${ }^{93}$ The majority held that 'the conditions precedent to the application of the doctrine [of legitimate expectations] were not established in this case'94 but nonetheless commented on the reach of the doctrine. The majority described legitimate expectations as 'an extension of the rules of natural justice and procedural fairness' that considers the conduct of an administrative decision-maker in the exercise of a discretionary power including 'established practices, conduct or representations' that can be characterised as clear and has in fact produced reasonable expectations of procedure or a certain benefit. ${ }^{95}$ The question of 'legitimacy' arises

86 See Greg Weeks, 'What Can We Legitimately Expect from the State?' in chapter 7 of this volume.

87 Moreau-Bérubé v New Brunswick (Judicial Council) 2002 SCC 11 ('Moreau').

88 Ibid, [78].

89 Ibid.

90 Mackin v New Brunswick (Minister of Finance) 2002 SCC 13 ('Mackin').

91 Ibid, [162].

92 CUPE v Ontario (Minister of Labour) 2003 SCC 29 ('CUPE').

93 Ibid, [110].

94 Ibid, [133].

95 Ibid, [131]. 
when looking to whether or not the expectations conflict with a statutory duty. ${ }^{96}$ In the result, the majority characterised past practices in the appointment of arbitrators as an implied requirement of the appointment power and the Minister, by failing to adhere to those practices, reached a patently unreasonable decision.

In Mavi ${ }^{97}$ the SCC considered the decision of Ontario to adopt certain procedures in light of federal statutory requirements, including whether Ontario had behaved reasonably or had fettered its discretion. The Court held that the legislation left Ontario with a measure of discretion, and that the procedure adopted by Ontario was compatible with the statute ${ }^{98}$ without conflicting with the intended scope of the discretion. ${ }^{99}$ The importance of policy as a guide to civil servants was recognised by the Court, as was the Minister's entitlement to set policy within legal limits. ${ }^{100}$ The Court stated that, in order to give rise to legitimate expectations, representations have to be within the scope of the decision-maker's authority. Reliance was held not to be required. ${ }^{101}$

The most recent ${ }^{102}$ and most potentially far-reaching discussion of legitimate expectations by the SCC is that in Agraira, ${ }^{103}$ which relates specifically to soft law. This unanimous judgment of a seven-member Court was concerned with a Minister's discretionary decision, required to be exercised after considering the 'national interest'. ${ }^{104}$ The appellant argued that the Minister took an excessively narrow view of the phrase 'national interest', and failed to meet a legitimate expectation that certain procedures would be followed and certain factors taken into account. ${ }^{105}$

While a staff briefing note indicated the petition should be granted, the Minister denied relief. The lower court had held that the Minister's reasons did not address the questions listed in the guidelines or factors identified by the courts as relevant. The SCC considered the reasonableness of the Minister's decision and referred to the guidelines as part of the reasonableness

96 Ibid, [131].

97 Canada v Mavi 2011 SCC 30 ('Mavi').

98 Ibid, [44].

99 Ibid, [65].

100 Ibid, [66].

101 Ibid, [68].

102 See Kanthasamy $v$ Canada (Citizenship and Immigration) 2015 SCC 61, where the majority of the Court reiterated that guidelines, though useful, are not legally binding and are not intended to be exhaustive or restrictive. The Court concluded that a discretionary decisionmaker who limited the criteria to be considered only to those set out in the Ministry guidelines acted unreasonably.

103 The issues related to the doctrine of legitimate expectations were considered to be incidental to the central issue of whether the Federal Court of Appeal (FCA) chose the correct standard of review and applied it properly: Agraira [2013] 2 SCR 559 [3], [47].

104 Relief could be granted where the person 'satisfies the Minister that their presence in Canada would not be detrimental to the national interest': ibid [42].

105 Ibid, [2]. 
assessment. ${ }^{106}$ The Court stated that, rather than being a fixed code, the guidelines contained 'a set of factors, which appeared to be relevant and reasonable' for the exercise of the particular discretion. ${ }^{107}$ The Minister was not required to apply them formulaically, but they should have 'guided the exercise of his discretion and assisted in framing a fair administrative process for such applications' and, as such, assisted the Court in understanding the Minister's 'implied interpretation of the "national interest"'. ${ }^{108}$

The doctrine of legitimate expectations was stated to be a 'particular face of procedural fairness' that can work to expand the procedural protections otherwise available. ${ }^{109}$ Legitimate expectations cannot give rise to substantive rights; courts are limited to granting only procedural relief. ${ }^{110}$ In Agraira, the Court held that the guidelines, which were publicly available, met the threshold requirements to give rise to a legitimate expectation. ${ }^{111}$ The Court stated that in this case the expectation was fulfilled. ${ }^{112}$ With regard to relevant factors outlined in the guidelines, the Court was of the opinion that where the guideline (irrespective of its source) is employed by the decision-maker in the making of the decision or in obtaining guidance for the exercise of discretion, and where the guideline is a relatively comprehensive code with respect to the decision of the exercise of discretion, then the factors listed must be considered.

Agraira has been influential in Canadian courts, ${ }^{113}$ though only a handful of decisions have relied on it to resolve matters related to legitimate expectations and the (mis)use of guidelines by administrative decision-makers. ${ }^{114}$ Of these decisions, only two have considered the substantive effect that guidelines can have when reviewing the reasonableness of an administrative decision-maker's exercise of discretion. ${ }^{115}$ In Pushparasa, the Federal Court

\footnotetext{
106 Guidelines can serve at least two distinct purposes. One is to inform the reasonableness analysis of a discretionary decision; the other is to determine whether the process was fair or not. Here, the broader context of the statutory provision 'includes the Guidelines' which, although not law 'in the strict sense', are 'a useful indicator of what constitutes a reasonable interpretation' of the particular provision: ibid [85].

107 Agraira (n 103) [60].

108 Agraira (n 103) [60].

109 Agraira (n 103) [94].

110 Agraira (n 103) [97].

111 Agraira (n 103) [98].

112 Agraira (n 103) [101].

113 As at 1 January 2016, Agraira had been cited in over 300 cases.

114 The majority of the decisions cited Agraira when dealing with (i) standard of review analysis, (ii) reasonableness of decisions, (iii) sufficiency of reasons, (iv) humanitarian and compassionate ground considerations under Immigration and Refugee Protection Act, (v) presumptions of consistent expression in statutes and modern rule of statutory interpretation, or (vi) a court of appeal's role when reviewing JR decision of lower court.

115 Frankie's Burgers Lougheed Inc $v$ Canada (Employment and Social Development) 2015 FC 27 ('Frankie's') and Pushparasa $v$ Canada (Citizenship and Immigration) 2015 FC 828 ('Pushparasa').
} 
(FC) stated that guidelines are useful in assisting the exercises of discretion (inherent in the decision), and may 'frame an administrative process for it to be reasonable and thus fair'. ${ }^{116}$ In Frankie's, the FC stated that broad, flexible adherence to guidelines set out in Agraira has 'many public benefits', including 'increased administrative efficiency, reduced backlogs, decreased scope for arbitrariness and increased certainty and predictability' ${ }^{117}$ Published guidelines were held to 'serve the useful role of giving rise to legitimate expectations regarding the assessment frameworks that will be followed by a public agency', and can serve as a useful indicator of what constitutes a reasonable interpretation of legislation. ${ }^{118}$

\section{Summary of Principles of Legitimate Expectations in Canada}

A claimant may have a legitimate expectation to a particular procedure, ${ }^{119}$ to have certain criteria considered as relevant, ${ }^{120}$ or to a particular substantive outcome. ${ }^{121}$ However, one cannot have a legitimate expectation that certain criteria, not made express by pronouncements or conduct of the decision-maker, will not be considered. ${ }^{122}$

Legitimate expectations are generated by a public body's clear, unambiguous and unqualified conduct. ${ }^{123}$ The conduct that can give rise to a legitimate expectation includes established practices, actions, or representations (oral or written, specific or general) of the public authority, ${ }^{124}$ or a closely related public authority whose guidelines are used in making the decision or guide the exercise of discretion. ${ }^{125}$ Also, to give rise to a legitimate expectation, the conduct must be within the scope of the decision-maker's statutory authority. ${ }^{126}$ These are objective criteria. Finally, there is no requirement of awareness of, or detrimental reliance on, the conduct by the claimant. ${ }^{127}$

116 Pushparasa, ibid [27].

117 Frankie's (n 115) [94].

118 Frankie's (n 115) [94]-[95].

119 Martineau (n 46), Old St Boniface (n 52); CAP (n 58); CUPE (n 91); Agraira (n 102); Baker (n 60); and Mount Sinai (n 68).

120 This is not strictly part of the legitimate expectations doctrine, though it is very closely related. The courts have considered conduct that would give rise to legitimate expectations as part of the reasonableness analysis of the decision on judicial review. See Baker (n 60). However, the SCC in Agraira (n 102), considered factors that would allow a claimant to have a legitimate expectation as to factors to be considered as set out in guidelines.

121 Baker (n 60); Agraira (n 103).

122 Agraira (n 103).

123 Mount Sinai (n 68) (Binnie J); Moreau (n 87); CUPE (n 92).

124 CUPE (n 92); and Agraira (n 102).

125 Agraira (n 103).

126 Mavi (n 97).

127 Mount Sinai (n 68) (Binnie J); and Mavi (n 97). 
As an extension of the rules of procedural fairness, ${ }^{128}$ legitimate expectations may both extend procedural protections beyond what the circumstances may otherwise require, ${ }^{129}$ and determine what procedures the duty of fairness requires in any circumstances. ${ }^{130}$ The conduct of the administrative decision-maker is useful to the courts as an indicator of fairness since it represents the expert administrator's view of what constitutes fair procedure in the circumstances. ${ }^{131}$ Legitimate expectations relate both to procedural and substantive accountability for decision-making, but result in only procedural remedies.

Although the SCC has stated that legitimate expectations only give rise to procedural protection, there is a range of substantive legal effects that flow from legitimate expectations. As part of the Court's application of the proper standard of review, the analysis of reasonableness under administrative law appears closely linked to its legitimate expectation reasoning. For example, in Baker, the Court justified its finding that the decision-maker had acted unreasonably in part because she failed to consider the applicable guideline. In this way, while legitimate expectations have developed in Canada as a procedural doctrine, the doctrine's analytic roots appear to be shared with substantive forms of review. ${ }^{132}$

\section{LEGITIMATE EXPECTATIONS IN THE TAX ADMINISTRATION CONTEXT}

Having explored the sources of soft law in the Canadian tax administration context and the development of legitimate expectations in Canadian administrative law, we now return to explore what impact, if any, legitimate expectations may have in arguably the richest setting of soft law in the Canadian legal system.

\section{Courts' Current Treatment of CRA Soft Law}

There are no SCC decisions that deal with the doctrine of legitimate expectations in the tax administration context. We will however briefly examine some Federal Court of Appeal (FCA) and Tax Court of Canada (TCC)

28 Old St Boniface (n 52); CAP (n 58); CUPE (n 91); and Agraira (n 103).

129 Old St Boniface (n 52); CAP (n 58); CUPE (n 92); and Agraira (n 103).

130 Baker (n 60).

131 Martineau (n 46). See also Baker (n 60).

132 Baker (n 60); and Agraira (n 103). 
decisions. ${ }^{133}$ The FCA has consistently held that 'policy guidelines do not create legitimate expectations of substantive rights', ${ }^{134}$ and has classified taxpayers' request to have the Minister review the matter in accordance with CRA policies and publications as 'a substantive right, in procedural language'. ${ }^{135}$ CRA publications and materials have no legal force and are not determinative. ${ }^{136}$ Taxpayers cannot rely on CRA publications and other administrative positions, and cannot rely on express promises or views expressed to another taxpayer in advance tax rulings (despite the CRA's position and consistent practice of regarding such rulings as binding as between the CRA and that particular taxpayer). ${ }^{137}$

This body of law, however, pre-dates the most recent developments in the legitimate expectations doctrine and soft law, particularly the Supreme Court's decision in Agraira. Older judicial statements about income taxation may also be vestiges of a time where taxation was viewed merely as confiscation of private property by the state-an attitude that, until quite recently, prompted the courts to interpret tax legislation narrowly and strictly as legislation designed to impose penalties. The assumptions and attitudes that underlie an approach holding tax law as 'unique' warrant critical re-examination in light of the change in the role that income taxation plays in modern, welfare democracies.

Legitimate expectations in the tax setting are framed by a legal context in which each assessment of each individual's tax liability in each year is considered afresh. In Ludmer ${ }^{138}$ the Federal Court confirmed that a tax authority was not bound by a concession made in one year to have to make the same concession in other years even if there was no change in law. ${ }^{139}$ In other words, by applying the law to a person's tax liability one way in one year, no legitimate expectation is created on which that person can rely to suggest that similar approaches are taken in the future. This is because the tax authority is authorised to assess each individual taxation year independently, ${ }^{140}$ making an assessment conclusive only for the year to which it

133 Although the SCC has not addressed legitimate expectations in the context of tax administration, it has held that CRA's administrative guidelines are 'not determinative but are entitled to weight and can be an "important factor" in case of doubt about the meaning of legislation': Nowegijick $v$ R [1983] 1 SCR 29 [28].

134 Oberlander $v$ Canada (AG) 2004 FCA 213.

135 Johnston Canyon Co Ltd v Canada (AG) 2009 FCA 219 [32].

136 See Nowegijick (n 133).

137 See Woon $v$ MNR (n 39). The authors have not encountered any recent decisions in respect to such rulings, likely due to the CRA's administrative practice.

138 Ludmer $v$ Canada [1995] 2 FC 3 (FCA) ('Ludmer').

139 Ibid, citing Admiral Investment Ltd $v$ MNR [1967] 2 Ex CR 308.

140 See Ludmer (n 138). A limited amount of certainty is provided by the time limitations the ITA places on the Minister's power to assess, additionally assess, or reassess a taxpayer. 


\section{Sas Ansari and Lorne Sossin}

applies, and allowing the tax authority to take a different view in a different year. ${ }^{141}$ So long as these inconsistent assessments are issued in good faith and are supported by the law, the courts will not interfere.

Aside from this case specific approach, the doctrine of legitimate expectations is treated the same way in tax administration as in the SCC decisions. Just as estoppel generally cannot lie with respect to an opinion or interpretation of the law, ${ }^{142}$ and cannot lie where it is invoked to prevent the exercise of a statutory duty or the application of law, ${ }^{143}$ legitimate expectations cannot compel a particular application of the Income Tax Act. ${ }^{144}$ Rather, guidelines issued by the CRA are held to reflect government policy as to the meaning and scope of the legislation. ${ }^{145}$ The Courts have viewed the interpretation of the Act as their responsibility, and that government policy as reflected in soft law cannot bind that interpretive role. ${ }^{146}$ On this basis, the FCA has stated that the Minister is not bound in the present or the future by CRA's guidelines. ${ }^{147}$ However, a taxpayer may use the CRA's guidelines to support an argument that the interpretation in the guidelines is correct. ${ }^{148} \mathrm{In}$ this sense, soft law in this context has legal relevance, even if not enforceable per se. Can soft law by itself ground an argument of unreasonableness or unfairness? The short answer in Canada now appears to be affirmative on both fronts. That said, the circumstances in which guidelines or other forms of soft law play a role in legal consequences remains to be fully explored.

For example, in the voluntary disclosure programme, which uses the discretion of the Minister to waive interest and penalties, several cases have held the Minister to the conditions for and the substantive relief promised in the applicable Information Circular. In Karia ${ }^{149}$ the FC held that although Information Circulars are not delegated legislation and have no force of law

141 ITA s $152(8)$

142 Ludmer (n 138), citing Stickel $v$ MNR [1972] FC 672, 681. See also JP Morgan Asset Management (Canada) Inc v Canada (National Revenue) 2012 FC 651 [76] (information bulletins of the CRA do not create estoppels).

143 Ludmer (n 138), citing Canada (Minister of Employment and Immigration) $v$ Lidder [1992] 2 FC 621 (CA) 625: 'common sense would dictate that one cannot fail to apply the law due to the misstatement, the negligence or simply the misrepresentation of a government worker'.

144 Ludmer (n 138).

145 Ludmer (n 138), citing Vaillancourt v Deputy MNR [1991] 3 FC 663 (CA) 674.

146 Unlike in the UK, where a taxpayer is limited to an appeal on a point of law only, in Canada a taxpayer may appeal to the TCC and challenge both the facts and the law in a full trial (see Ludmer (n 138)).

147 Ludmer (n 138). See Stickel v MNR [1972] FCJ no 53, reviewed on other ground by the FCA in 72 DTC 6178 (FCA), subsequently affirmed by SCC in 74 DTC 6269 (SCC); see also MNR $v$ Inland Industries [1971] SCJ 145.

148 Ludmer (n 138), citing Vaillancourt (n 145) 674. See also Harel $v$ The Deputy Minister of Revenue in the Province of Quebec, [1978] 1 SCR 851 and $R v$ Nowegijick [1983] SCJ o 5, 83 DTC 5041 (SCC).

149 Karia v Canada (MNR) 2005 FC 639 ('Karia'). Karia was never appealed but was followed in Wong $v$ Canada (National Revenue) 2007 FC 628. 
'as such', promissory estoppel would operate to prevent the Minister with the necessary lawful authority from exercising discretion contrary to the promise contained in the Information Circular. ${ }^{150}$ Where the requirements for estoppel have not been met, the FC has held that Information Circulars are not binding on the Minister in the exercise of discretion. ${ }^{151}$ Further, guidelines have been held to be relevant in assessing the reasonableness of the Minister's decision when exercising discretionary powers. ${ }^{152}$ Whatever the role of guidelines in setting out relevant considerations the weight to be assigned to the relevant and competing factors, within a range of reasonable outcomes, is for the decision-maker alone. ${ }^{153}$

The TCC held in Wollenberg, in reference to the provisions that set a taxpayer's liability rather than those which deal with tax administration, that:

what Parliament has decreed shall be the rules applicable in determining what is payable by way of tax under the provisions of the Act is paramount and cannot be repealed or amended in any manner by whatever Revenue Canada may choose to publish by way of Tax Guides, Interpretation Bulletins, or otherwise. ${ }^{154}$

In the context of the substantive tax provisions, such publications have some limited legal consequences. ${ }^{155}$ Where a provision is ambiguous, such that there is doubt as to its meaning, guidelines are 'entitled to weight' and can be an 'important factor' in the process of proper interpretation. ${ }^{156}$ However, courts have refused to simply rely on administrative practice when provisions are unclear. ${ }^{157}$ Where a policy contradicts the wording of the provision or otherwise takes a position not supported by the legislation, it can be of no help. ${ }^{158}$ Administrative practice has an asymmetrical operation which can

150 Karia (n 149) [7]-[9].

151 See eg Brown v Canada (Customs and Revenue Agency) 2005 FC 1639 [27] (Information Circulars 'cannot exclude all other valid and relevant reasons for which the Minister might exercise his discretionary authority or refuse to do so').

152 See Telfer $v$ Canada (Canada Revenue Agency) 2008 FC 218 [13], citing Jim's Pizza (1980) Ltd v Canada (Revenue Agency) 2007 FC 782 (Minister's discretionary power to waive interest). This decision was overturned on appeal, 2009 FCA 23, on the basis that the decision was not unreasonable.

153 Canada $v$ Telfer 2009 FCA 23.

154 Wollenberg $v$ MNR 84 DTC 1055 (TCC) ('Wollenberg'). See also Gallant $v$ The Queen 2013 TCC 119 (taxpayer used CRA forms required to be submitted with his return to calculate a deduction greater than what the Act allowed; held that it was unfair to require the taxpayer to perform calculations according to the form and then assess on a different basis, but the appeal was dismissed because estoppel could not operate to stop the application of the law).

155 Wollenberg (n 154).

156 Wollenberg ( $\mathrm{n}$ 154). See also Harel $v$ Québec (Deputy Minister of Revenue) [1978] 1 SCR 851.

157 Brelco Drilling Ltd $v$ The Queen 98 DTC 1422 (TCC) 430.

158 Wollenberg ( $\mathrm{n}$ 154). This is linked to the doctrine of fettering of discretion by an administrative decision-maker. 
be used to resolve doubt in favour of the taxpayer, but not in favour of the administrative decision-maker that formulated the guideline. ${ }^{159}$

\section{CRA Guidelines and the Agraira Criteria}

In Agraira, the SCC held that in order for guidelines to be able to give rise to legitimate expectations, the guidelines must be:

(1) publicly available;

(2) used to make a decision or guide an exercise of discretion; and

(3) a 'relatively' comprehensive code with respect to making that decision or exercising that discretion.

Of the six CRA guidelines described in the first part of this chapter, which would meet all three conditions?

The first criterion is that the guidelines be publicly available, but the Court did not say that the agency that created the guidelines must make them publicly available, that they must have been intended for the public, or that they be available to the person seeking to rely on them. All six CRA guidelines are publicly available: Folios, ITs, ICs, ITTN, and Tax Guides and Pamphlets are all made available to and are intended to be consulted by the public. ATRs, however, are not publicly available, though members of the public may access them through access to Information legislation. ${ }^{160}$ If ATRs are publicly available for the purposes of the Agraira analysis, then almost all government guidelines would qualify provided that someone has at some point requested and been granted access to them.

The second criterion is that the guidelines are used by the decision-maker in making a decision or for the purpose of guiding an exercise of discretion. This criterion appears to be more challenging in respect to the six guidelines discussed. On the surface, none of the six are expressly stated to be used to guide decisions or exercises of discretion, since the staff manuals are expected to be used by CRA decision-makers. ${ }^{161}$ However, when looking at the content of the internal staff manuals and comparing them to the guidelines considered in this chapter, the substantive content of the two are for all intents and purposes identical. Also, quite often, the manuals refer

159 See Canadian Occidental US Petroleum Corp v Canada [2001] TCJ No 112 (QL) [30].

160 As with the various manuals that CRA employees use to make decisions and exercise power every day, ATRs are only available to a section of the public that has paid for access through a commercial publisher.

161 There are a number of manuals that are used by CRA employees, eg the Appeals Branch Reference Materials include the Taxpayer Relief Reference Guide which is intended to be a 'complete and up-to-date guidelines on how to apply the taxpayer relief provisions' and 'easyto-use reference that has information you need to process taxpayer requests'. 
the CRA employee to outside sources, including: ICs; Guidelines and Pamphlets; ITs; ATRs; and ITTN. The only type of guideline referred to in this chapter that is not mentioned in the CRA employee manuals are the Folios, likely because they are too recent to have been incorporated explicitly into the manuals. ${ }^{162}$ Therefore, all six guidelines would likely meet this criterion, given their incorporation into the employee manuals used by CRA employees in making decisions or exercising discretion.

The third criterion, that the guideline be a relatively comprehensive code with respect to that decision or that exercise of discretion, will likely be satisfied given that each of the six guidelines, at least with respect to the matters they do address within the topics they are geared towards, is relatively complete. This analysis must, however, be made on a guideline-by-guideline basis.

In light of the Agraira criteria and the context of CRA soft law, lower court rulings suggesting there is no legal obligation on CRA officials to consider guidelines is now suspect. Indeed, it may well be that areas of law with dense and long-standing uses of soft law, like tax administration, will lead Canada's doctrine of legitimate expectations in new directions.

\section{CONCLUSIONS}

This chapter has canvassed the evolution of the Canadian legitimate expectations doctrine with specific reference to soft law in the income tax context. We have used a representative sample of soft law instruments to show how the criteria developed by the Supreme Court of Canada might alter the way in which those guidelines are understood from the perspective of legitimate expectations. Where once these instruments were seen as not giving rise to procedural or substantive rights to have guidelines considered or followed, there now appears to be good reason to rethink the legal implications of soft law. In this way, we have attempted to grapple both with the legal principles explored by Canadian courts and the administrative realities in which those principles must resonate.

The development of legitimate expectations cannot be isolated from a broader trend moving towards a greater 'ethos of justification' in the administrative state and administrative justice. Chief Justice McLachlin described this trend in the following terms:

$[S]$ ocieties governed by the Rule of Law are marked by a certain ethos of justification. In a democratic society, this may well be the general characteristic of the Rule

162 All Folios refer to ITs and ITTNs that they replace, so it can reasonably be assumed that where a reference is to an IT or ITTN that has been replaced by a Folio, the CRA employee will look to the Folio for guidance. 
of Law within which the more specific ideals ... are subsumed .... Where a society is marked by a culture of justification, an exercise of public power is only appropriate where it can be justified to citizens in terms of rationality and fairness ... The Rule of Law, in short, can speak in several voices so long as the resulting chorus echoes its underlying values of rationality and fairness (emphasis added). ${ }^{163}$

An 'ethos of justification' includes the idea that 'arbitrary state action [is] impermissible' such that 'the exercise of power must be [...] justifiable and justified' so that citizens see, ${ }^{164}$ through the fog of government action, the 'underlying values of rationality and fairness'. ${ }^{165}$ In Canadian administrative law, procedural fairness, substantive review for reasonableness or correctness (depending on the standard of review), and monitoring of jurisdiction together serve to advance and promote a culture of justification. ${ }^{166}$

The intersection of soft law and legitimate expectations can advance the project of justification in several ways. Specifically, by recognising that soft law can give rise to legitimate expectations, the Supreme Court has opened up new avenues for enhancing the transparency and accountability of administrative action. At least in the circumstances confirmed in Agraira (but perhaps more broadly), guidelines of the kind discussed in this chapter in relation to tax administration can give rise to enforceable expectations. Soft law and legitimate expectations provide a framework for ensuring greater consistency and coherence in the exercise of discretion-and where it can be justified, also ensure transparency if and when administrative decision-makers depart from guidelines and other policy instruments.

Legitimate expectations invite greater attentiveness to context in the review of administrative action. Administrative bodies come in all manner of configurations of powers, duties, obligations, purposes and roles. They combine, in various ways, administrative, investigatory, and judicial roles in pursuit of efficient, effective, and even-handed implementation of government goals. Given this variety, courts should consider a number of factors when considering the legal effect to be given to soft law instruments. While it is premature to describe exhaustively the scope and nature of these factors, the goal of advancing the 'ethos of justification' suggests at least some

163 Chief Justice McLachlin, 'The Roles of Administrative Tribunals and Courts in Maintaining the Rule of Law' (1999) 12 Canadian Journal of Administrative Law and Practice 171, 174.

164 CES Ned Franks, 'To Prorogue or not to Prorogue: Did the Governor General Make the Right Decision' in Peter H Russel and Lorne Sossin (eds), Parliamentary Democracy in Crisis (University of Toronto Press, 2009).

165 Wollenberg (n 154).

166 See David Dyzenhaus, 'The Politics of Deference: Judicial Review and Democracy' in Michael Taggart (ed), The Province of Administrative Law (Hart Publishing, 1997) 279. See also D Dyzenhaus and E Fox-Decent, 'Rethinking the Process/Substance Distinction: Baker v. Canada' (2001) 51 University of Toronto Law Journal 193. 
of these considerations. For example, where the legislation applies to the general public, a vulnerable sub-group of the public, where it applies irrespective of deliberate action by the person, where the statute is complex or voluminous, where the words conferring the discretionary power are general or broad, where the nature of the discretion is punitive or relieving, and where the consequences of mistakes can have significant effects on the person's daily life, soft law instruments are more likely to be useful, consulted, and relied on. They ought therefore to be given greater consideration by courts when the guideline supports or favours the private person's position or interest. Further, where the instrument sets out a procedure to be followed and the conditions under which discretionary power will be exercised, guidelines ought to be given greater weight.

While the potential of legitimate expectations in relation to soft law is significant, as demonstrated by the setting of tax administration, considerable uncertainty remains. The sharp distinction drawn in Canadian administrative law between the procedural and substantive implications of legitimate expectations is difficult to sustain. The analysis of relevant factors in the legitimate expectations analysis in the context of soft law remains largely undeveloped. In our view, the importance and variability of soft law in the administrative state will continue to drive the development of legitimate expectations. Canadian administrative law is poised to develop a more coherent and transparent doctrine of legitimate expectations. At the same time, a richer understanding of legitimate expectations can serve as a vital catalyst for sorting out the place of soft law within broader rule of law commitments. 
